\title{
Results after Five Years of Intensive Leprosy Control Work in a Highly Endemic Area*
}

\author{
K. SURESH \\ R. S. MANI \\ A. KRISHNA RAO \\ D. MADHAVA RAO \\ Danish Save the Children Organization, Pugiri, Andhra Pradesh, India
}

\section{INTRODUCTION}

The Leprosy Control Project sponsored by the Danish Save the Children Organization was started in 1962 in 2 highly endemic districts, Srikakulam and Visakhapatnam. The project is assisted by the United Nations Children's Fund (UNICEF) and the Governments of Andhra Pradesh and India, and receives technical guidance from the World Health Organization (WHO). It expanded gradually till it reached its present maximum size in 1966 , and now covers an area of 2200 sq. miles $(5630$ sq. $\mathrm{km})$ and a population of 15 lakhs $(1,500,000)$. At present, 33,224 patients are under treatment, of whom 29,675 are living inside the project area, and 3549 come from outside it.

The primary aim of the project is to control leprosy in this part of Andhra Pradesh by treating all existing patients, thus reducing the number of circulating bacilli, and so check the spread of the disease in the community.

\section{ORGANIZATIONAL SET-UP}

There are 70 units in the project, with one clinic in each of them. The units are grouped into 5 zones, each headed by a zonal supervisor, assisted usually by 2 senior leprosy auxiliary workers. Care is taken to maintain the optimum ratio of one member of the supervisory staff for every 5 auxiliary workers.

One leprosy auxiliary worker is in charge of one unit and is responsible for case-finding and treatment of all patients in a population of about 20,000 , living in a 3 or 4 mile $\left(5\right.$ to $\left.6 \frac{1}{4} \mathrm{~km}\right)$

*Received for publication 2 September, 1969. radius. The average number of "inside-area" patients treated in each clinic is 413. The clinics are held once a week and are planned in such a way that all are attended in rotation by one of the members of the zonal supervisory staff. He supervises the treatment, takes all important decisions, and after the clinic is over assists the worker in preparing his programme for the ensuing week.

The main functions of the leprosy auxiliary worker are health education of the public, contact examination, school surveys, and tracing of absentees in the villages of his unit. The zonal supervisor, though continuously guided by the senior supervisory staff from the Centre, is fully responsible for the planning and implementation of all activities going on in his zone, in close co-operation with his 2 senior leprosy auxiliary workers.

At the Centre there is a hospital with 50 beds and physiotherapy and laboratory facilities. Patients in need of intensive medical care, especially because of acute episodes, can be admitted to the hospital. Those suffering from intercurrent diseases are advised to attend general health centres or hospitals with which the Project maintains close co-operation. Besides the patients admitted specifically for physiotherapeutical treatment, the physiotherapy unit provides special care for all other patients in the hospital according to their disabilities and visits are also paid to the peripheral clinics at regular intervals, mainly to teach the patients how to live with anaesthetic hands and feet and to show how secondary deformities can be prevented. 
Bacteriological examination is done in doubtful cases for confirmation of diagnosis or for classification. It is repeated twice a year in all positive cases, smears being taken at the clinics and brought to the Centre for examination.

\section{CASE FINDING}

The main methods of case-finding consist in health education, contact survey, and school survey. In about two-thirds of the cases detected the patients came spontaneously to the clinics, influenced by the intensive health education, through the leprosy auxiliary worker, who is in close contact with the local population and takes an active part in the daily life of the villagers. The remaining cases are detected by examination of contacts and school-surveys, which are carried out twice a year.

A mass-survey is done in a pilot area as a built-in assessment of the standard case-finding methods and as an evaluation of the results achieved.

\section{CASE MANAGEMENT AND CASE HOLDING}

The leprosy auxiliary worker (L.A.W.) conducts the clinic once a week from 7 a.m. to 12 noon in the presence of a member of the zonal supervisory staff. As a rule patients raceive drugs sufficient for 4 weeks and are briefed about the possible side-effects of the drugs, which in practice are found to be very few. A list of absentees and of patients who are expected to attend the next clinic is prepared at the end of the clinic session, along with the L.A.W's tour programme.

He then visits the patients who failed to attend, finds out the cause, gives advice and counselling, and persuades them to attend next clinic; he also carries out contact survey and school survey as per programme. Domiciliary treatment is given only to physically disabled patients, as decided by the supervisory staff.

\section{DEVELOPMENT OF THE PROJECT}

The number of treated patients has increased gradually to reach its maximum at the end of the first half of 1967 , when 30,087 patients were treated. Since then it has remained more or less stationary, fluctuating between 28,732 at the end of 1967 and 29,675 at the end of 1968 .

The gradual expansion of the project from 1962 to 1966 (see Table 1) renders the interpretation of the evolution of the case-load very arduous.

TABLE 1

Development of the project

\begin{tabular}{lcccc}
\hline Year & No. of new & Population & \multicolumn{2}{c}{ Area } \\
& units opened & covered & sq. miles & sq. km. \\
\hline 1962 & 9 & 169,272 & 400 & 1035 \\
1963 & 22 & 484,038 & 500 & 1295 \\
1964 & 9 & 146,907 & 300 & 777 \\
1965 & 15 & 346,157 & 500 & 1295 \\
1966 & 15 & 317,802 & 500 & 1295 \\
Total & 70 & $1,465,176$ & 2200 & 5697 \\
\hline
\end{tabular}

In 1962, the staff had to become acquainted with the local situation and to establish contact with the authorities, methods of case-finding and case-holding had to be evolved, and auxiliary staff trained.

All these activities, unavoidable when establishing a new centre, inevitably delayed the elaboration of all activities in a systematical way, and caused some loss of time.

\section{EVOLUTION OF THE CASE-LOAD IN THE UNITS STARTED IN 1963}

The units which were started in 1963 give the most uniform and realistic picture of the results and achievements, after 5 years of intensive control work. In that year 22 control units were started, covering a population of 484,038 . In this paper it is proposed to discuss only these units.

The first patients to be registered were the most obvious cases, although from the very establishment of the units a start was made with intensive case-finding. In 1964, after one year of functioning, 2881 new patients had been found. This number (i.e. of new detections) remained more or less stationary for 3 years and then dropped to approximately half, after 4 or 5 years of intensive control work. The high 
TABLE 2

Evolution of case-load in units opened in 1963

\begin{tabular}{|c|c|c|c|c|c|c|}
\hline Year & $\begin{array}{l}\text { New cases } \\
\text { detected }\end{array}$ & $\begin{array}{l}\text { Rate/1000 } \\
\text { population }\end{array}$ & $\begin{array}{l}\text { Cases released from } c \\
\quad \text { No. }\end{array}$ & $\begin{array}{l}\text { control } \\
\%\end{array}$ & $\begin{array}{c}\text { Case-load at end } \\
\text { of the year }\end{array}$ & $\begin{array}{l}\text { Rate/1000 } \\
\text { population }\end{array}$ \\
\hline 1963 & 5937 & 12.0 & - & - & $5424 *$ & 11.2 \\
\hline 1964 & 2881 & 6.0 & - & - & 7634 & 15.8 \\
\hline 1965 & 2351 & 4.8 & 2 & 0.02 & 9150 & 18.9 \\
\hline 1966 & 2596 & 5.3 & 56 & 0.5 & 10724 & 22.2 \\
\hline 1967 & 1509 & 3.1 & 1433 & 12.3 & 10189 & 21.1 \\
\hline 1968 & 1133 & 2.3 & 2353 & 18.8 & 10131 & 20.9 \\
\hline
\end{tabular}

No. of control units, 22; population covered, 494,038.

*The difference between the total detections and case-load at the end of the year represents the cases which were not registered and those patients who died or left the control ared.

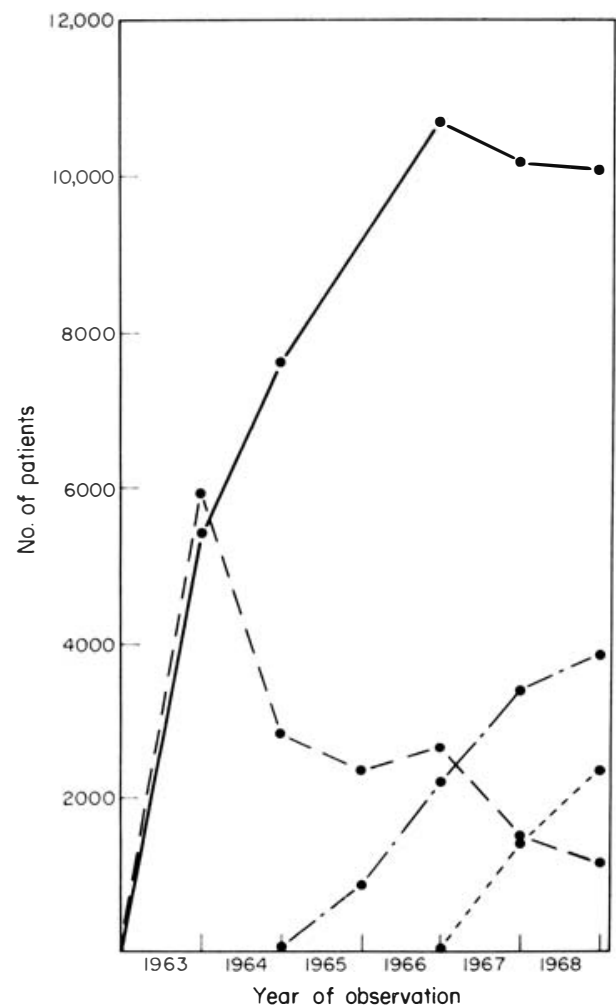

FIG. 1

Evolution of case-load, in 1963 units. - Case-load; $-\ldots-\ldots$, new cases detected; $-\ldots \ldots$, inactive cases; ..... released from control. figure in the first year and the following 3 years could be due to the accumulation of cases before the start of the project.

After 2 or 3 years, a few patients could be released from control, mainly from among those who had already been receiving treatment for some time before the Project was started. But after 4 years $1433(12.3 \%)$ of the existing number of patients were released from control, and after 5 years $2353(18.8 \%)$ of the total number of patients were released.

During these 5 years, of course, some of the patients died or left the control area. No mention has been made of them because of their very limited influence on the consideration of the results obtained. The case-load at the end of each year is mainly a balance between the newly detected patients and those released from control (see Table 2).

Table 2 and Fig. 1 show a steady increase in the case-load until 1966 after 3 years of control. This figure remains stationary, with a slight tendency to decrease, up to the end of 1968 , after completing a period of 5 years.

It is very encouraging to observe in Table 3 and Figs 2 and 3 that the case detection rate of lepromatous cases falls more rapidly and more significantly than in the overall group of patients. Although no lepromatous patients are released from control, the load of infectious cases has remained stationary since 1966, after 2 or 3 years of control work, the number of new cases found being compensated for by the 
214 K. Suresh, R. S. Mani, A. Krishna Rao and D. Madhava Rao

TABLE 3

Evolution of lepromatous case-load in units opened in 1963

\begin{tabular}{ccccc}
\hline Year & $\begin{array}{c}\text { New } \\
\text { lepromatous } \\
\text { cases } \\
\text { detected }\end{array}$ & $\begin{array}{c}\text { Rate/1000 } \\
\text { population }\end{array}$ & $\begin{array}{c}\text { Lepromatous } \\
\text { case-load at } \\
\text { end of the } \\
\text { year }\end{array}$ \\
\hline 1963 & 1403 & \multicolumn{4}{c}{1000} \\
1964 & 347 & 0.7 & 1364 & 2.8 \\
1965 & 200 & 0.4 & 1603 & 3.3 \\
1966 & 158 & 0.3 & 1749 & 3.5 \\
1967 & 88 & 0.18 & 1725 & 3.6 \\
1968 & 85 & 0.17 & 1728 & 3.6 \\
\hline
\end{tabular}

No. of control units, 22; population covered, 494,038.

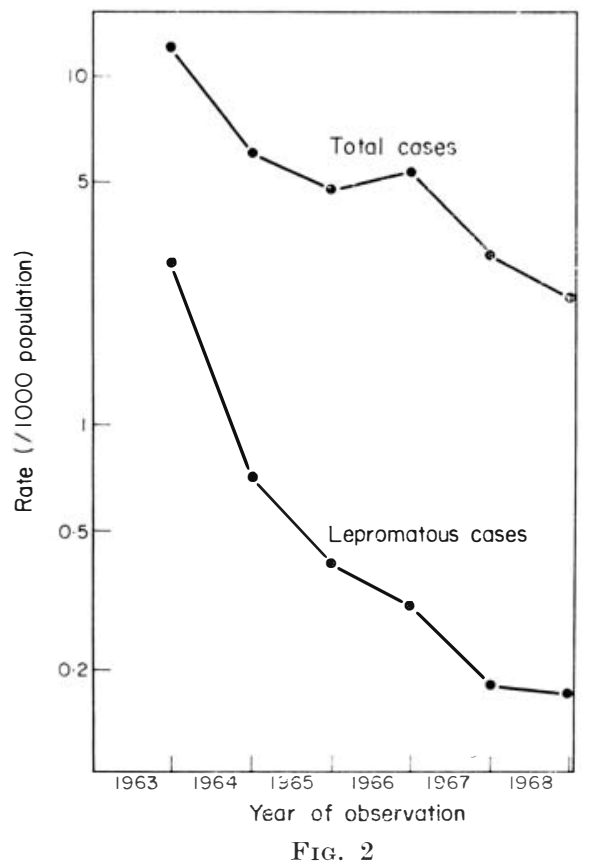

Annual rate of detection of new eases (total) and of lepromatous cases.

number of patients who died or left the control area.

As can be seen in Table 4, the proportion of lepromatous cases among the new cases decreased from $23.6 \%$, when the clinics were established, to less than $6 \%$ at the end of the observation period.

Even though the laboratory came into existence in 1963, it was not functioning in full swing in the initial stages. In $1964,67.7 \%$ of the
TABLE 4

Proportion of lepromatous cases among new cases detected

\begin{tabular}{lccr}
\hline Year & $\begin{array}{c}\text { No. of } \\
\text { new cases }\end{array}$ & $\begin{array}{c}\text { No. of new } \\
\text { lepromatous cases }\end{array}$ & $\%$ \\
\hline 1963 & 5937 & 1403 & 23.6 \\
1964 & 2881 & 347 & 12.0 \\
1965 & 2351 & 200 & 8.5 \\
1966 & 2596 & 158 & 6.1 \\
1967 & 1509 & 88 & 5.8 \\
1968 & 1293 & 85 & 6.6 \\
\hline
\end{tabular}

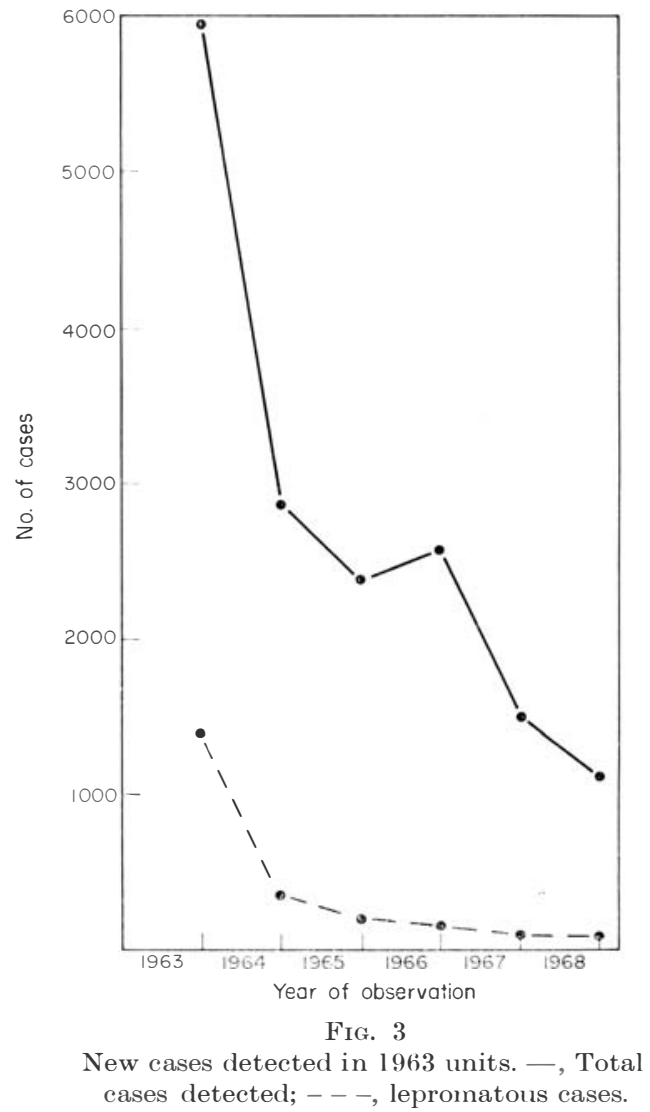

lepromatous patients were examined bacteriologically and $15.6 \%$ of them were found to be negative. These negative cases were treated previously by other organizations or in 1962 as "outside-area" patients. From 1965 onwards bacteriological examination was established and out of $92.7 \%$ examined bacteriologically, $24.9 \%$ were found to be negative. 
TABLE 5

Bacteriological results

\begin{tabular}{|c|c|c|c|c|c|}
\hline Year & $\begin{array}{c}\text { Total no. of } \\
\text { lepromatous cases }\end{array}$ & $\begin{array}{l}\text { Total no. of cases } \\
\text { examined bacteriologically }\end{array}$ & $\%$ & $\begin{array}{l}\text { Total no. of } \\
\text { negative cases }\end{array}$ & $\%$ \\
\hline 1963 & 1364 & 145 & 10.6 & 14 & 9.7 \\
\hline 1964 & 1603 & 1085 & 67.7 & 169 & 15.6 \\
\hline 1965 & 1696 & 1572 & 92.7 & 392 & 24.9 \\
\hline 1966 & 1749 & 1703 & 97.4 & 662 & 38.9 \\
\hline 1967 & 1725 & 1701 & 98.6 & 749 & 44.0 \\
\hline 1968 & 1728 & 1716 & 99.3 & 775 & 45.2 \\
\hline
\end{tabular}

Of the 1728 lepromatous cases existing at the end of 1968, $775(45.2 \%)$ have been rendered bacteriologically negative, while $953 \quad(55.8 \%)$ still remain bacteriologically positive. The morphological index (MI) is not determined as a routine in all bacteriological examinations, but most cases show bacillary fragmentation and in some the MI has been reduced to zero.

Patients who fulfil the requirements laid down by the WHO Expert Committee are declared inactive by one of the medical officers of the project. As can be seen in Table 6, the number of inactive cases increases gradually from 1965 onwards. At present $3875(38.2 \%)$ of the 10,131 existing cases show inactive lesions and are receiving maintenance treatment. since the great majority of these patients have tuberculoid-type disease they may be expected to be released from control in 1969/70.

TABLE 6

Evolution of case-load in units started in 1963

\begin{tabular}{lcccc}
\hline Year & $\begin{array}{c}\text { Case-load at end } \\
\text { of the year }\end{array}$ & $\begin{array}{c}\text { Rate/1000 } \\
\text { population }\end{array}$ & $\begin{array}{c}\text { Inactive } \\
\text { cases }\end{array}$ & $\%$ \\
\hline 1963 & 5424 & 11.2 & - & - \\
1964 & 7634 & 15.8 & - & - \\
1965 & 9150 & 18.9 & 834 & 9.1 \\
1966 & 10,724 & 22.2 & 2190 & 20.4 \\
1967 & 10,189 & 21.1 & 3388 & 33.3 \\
1968 & 10,131 & 20.9 & 3875 & 38.2 \\
\hline
\end{tabular}

\section{CONCLUSIONS}

In the 22 units established in 1963, the case-load has remained stationary since 1966 and fluctuates since then around 10,000. The number of new cases found is compensated for by the number of patients released from control.

If the figures show a gradual decrease in the number of new cases, the reduction in the number of new lepromatous cases is still more pronounced. One of the reasons to explain this observation may be that the vast majority of new cases are detected in such an early stage, that is, before they evolve into an infectious form.

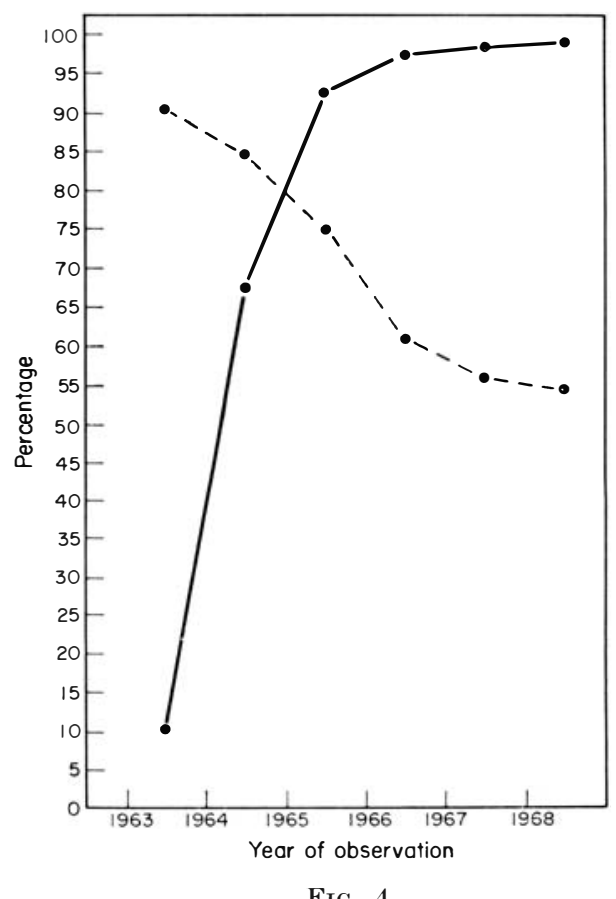

Bacteriological results, in 1963 units. - Bacteriologically examined cases (lepromatous); - - - , positive cases. 
Besides a dramatic reduction in the number of new lepromatous cases, more and more existing lepromatous cases become bacteriologically negative: $45 \%$ of 1728 lepromatous cases. Although no information is systematically maintained regarding the MI of the still positive patients, it is known to have become zero in some of them.

Apart from the reduction in the number of circulating bacilli, the clinical results of DDS treatment will contribute to the reduction of the case-load. At the end of 1968, the number of inactive patients is 3 times as high as the number of new cases detected: 1133 new cases against 3875 inactive cases.

The latter cases are mostly of the tuberculoid type and it is expected that most of these patients will be released from control in the very near future, 1969 and 1970.

The data collected after 5 years of intensive control work indicate that a decrease in the case-load may be expected soon. The results of specific mass-treatment allow us to release from control about as many patients as new patients come up.

A reduction in the number of circulating bacilli has certainly been obtained and it is expected, and hoped, that this reduction will be of such a degree that it will decrease, if not entirely intercupt, the incidence of transmission, with an appreciable reduction in the appearance of new cases in the community.

\section{REFERENCES}

KEJA, A. and Brogger, s. An assessment of the Leprosy Control Project, Pogiri. Parts I and II (SEA/LTC$1 /$ WP2 and WP3).

MALlAC, M. J., WHO leprologist (1964). Assignment Report on Leprosy Control Project, Srikakulam, Andhra Pradesh (SEA/Lep/17, dated 28 March, 1964).

KEJA, J. (1967). Assignment Report on Leprosy Control, Pogiri, Srikakulam, Andhra Pradesh (SEA/Lep/24, dated 7 April, 1967).

KeJA, J., BRogger, s. and MANI, R. s. Manual for Leprosy Auxiliary Workers, Pogiri (SEA-I.TC/ 1WP6).

WHO EXPERT COMMITTEE ON LEPROSY-3RD REPORT (1966). Wld Hlth Org. Tech. Rep. Ser., 319. 